\title{
Towards sustainable coastal planning and policies from a Malaysian perspective
}

\author{
D.' Y. bin Nordin \\ Federal Department of Town and Country Planning, \\ Ministry of Housing and Local Government, Malaysia
}

\begin{abstract}
Malaysia, with a land area of some $330,000 \mathrm{~km}$ square and a coastline of some $4,800 \mathrm{~km}$, sits on the geologically stable Sunda Shelf. Half the coastline consists of beaches and slightly less than half is mangrove fringed; there is little rocky coast. It has been estimated that some $30 \%$ of the coastline is subject to varying degrees of erosion. The population of 25 million is small for a country in the region but its population growth rate of some $2.4 \%$ is amongst the highest. Over $60 \%$ of the population lives along or close to the coasts.

Growing populations not only put a greater strain on already depleting resources, but are also responsible for the degradation of marine habitats for those resources. Since the oceans have limited resources, there is a need to minimize the impact that the growing size and number of coastal communities have on marine environments. Development along the coasts and hinterland has been extensive. Erosion is significant and may contribute to coastal sedimentations rates (in protected areas). Many coastal areas (especially where mangroves occur) have been bounded and reclaimed. Fishermen's livelihoods and marine life along coastal areas have also been affected.

The weakness of conflict resolutions, inadequate enforcement, insufficient environmental resources data and lack of co-ordination and funding are among the critical issues on the coast. Malaysia has taken a precautionary approach and multi-sectors integration. Policies and acts have been formulated to strengthen effective and applicable guidelines and there are by-laws to control and manage the coastal area development. Integration between marine sectors and spatial (land-based sectors) was important to achieve sustainable use of the coastal area.

The Malaysia coastal zone complex system of atmospheric, marines and terrestrial natural forces needs a systemic approach to planning and development. Proper integrated coastal management planning provides indications towards an integrating coastal ecosystem and the strategic importance of renewable resources for socio-economic development which involves the coordination of process, procedures, acts, regulations and jurisdictions.
\end{abstract}

Keywords: populations, depleting resources, development, conflicts resolutions, policies and approach, integrated management. 


\section{Introduction}

Throughout history civilizations have developed on the water's edge. The vast resources of the oceans are an essential element for the survival of coastal communities. Ironically, the world marine environments are also disposal systems for human generated waste. There is some truth in saying everything comes from the sea and everything returns to the sea. The implication is that since the oceans have limited resources, there is a need to minimize the impact that the growing size and number of coastal communities have on marine environments. Although non-coastal communities also have pressing environmental issues such as landslides, forest clearances for development purposes, but maintaining sustainability in coastal development is particularly important in Malaysia. It is because the extent of land mass in the coastal zone of Malaysia is estimated to be 4.43 million hectares (13\%) of the total land area in the country. The coastal zone of Malaysia has a special socio-economic significance. A large majority (about $60 \%$ ) of the total population live in the coastal zone. The coastal zone is also the centre of economic activities encompassing urbanisation, agriculture, fisheries, aquaculture, oil and gas exploitation, transportation and communication, industries etc. Almost $21 \%$ of the coastal areas have been developed for mainly for housing, transportation and tourism purposes.

\section{Coastal planning in Malaysia}

The rapid development of Malaysia's economic activities in coastal area will lead to problems such as degradation of maritime resource and social environment if not properly planned and manage to achieve sustainable development. It is significant because fishing and farming industries contribute about $13.6 \%$ to Malaysian GDP. At this juncture, it is difficult to identify precisely the actual population related to fishing industries. The only available figure is total of 383 fishing villagers in Peninsular Malaysia (244 in west coast and 139 in east coast). The fishing villagers solely depend on coastal activities such as fishing, tourism supporting activities as a source of income. So, sensitive planning in the fields of coastal area management, prevention and reduction of pollution, ecosystems and biological diversity conservation is extremely crucial to protect Malaysia's maritime resources and social communities in coastal areas.

\subsection{Issues on coastal planning in Malaysian contacts}

Recent surveys done by UNDP-GEF Projects indicate that the Malaysian marine parks constitute a globally important area for marine biodiversity. However, there is a range of factors having increasing negative impacts on marine biodiversity. The primary issues threats to biological diversity and ecological integrity in the marine parks of Malaysia have been identified as follows: 
- Declining fish stocks and exploitation of breeding grounds

- Loss of habitat for marine life and destruction of coral reefs

- Habitat degradation and degradation of water quality

The growing population, economy and technology in Malaysia allowed an exponential increase in the 'development' of coastal areas. Land-based activities such as developments of port, development of islands for tourism purposes and urban development and reclamation cause implication towards declining of fish stocks, loss of habitat for marine and degradation of water quality.

\subsubsection{Development of ports}

Developments of ports in Malaysia such as Klang Port (west coast) and Tanjung Pelepas (south coast) caused declining in fish stocks. In year 2004, Malaysia have exported varies type of fish which equivalence to RM1.293 ringgit billion only to Singapore, Japan, Europe and at the same time have imported up to RM1.217 billion ringgit for own consumption. Coastal pollution caused by the ships spoils the marine life and affect fisherman income particularly. These problems also caused implication towards Small Medium Industries (SMI) which mainly depends on fishing for products such salted dry fish industries, crackers (keropok), ikan bilis, sardines etc. Destroying mangrove forests for development of ports significantly declining the population of marine life such as fishes, prawns and mud crabs and would affect the livelihood of mangrove fishermen. The issues now are how we are going to sustain this marine life and fishermen income in long term conserving these areas without jeopardising the port development.

\subsubsection{Development of island for tourism purposes}

The coastal areas in Malaysia have plenty of opportunities, particularly in the further development of tourism. In year 2004, about 14.07 million tourist visited Malaysia compared to 8.1 million in year 2003 and expected to increase in coming years. Tourism sector generates a range of impacts on economy growth, but at the same time generate problems for the resource base on which their survival depends and cause conflicts between sectoral interests. Development of some famous islands in Malaysia such as Tioman Island (west coast of Peninsular of Malaysia), Langkawi Island (east coast of Peninsular of Malaysia) caused implication towards marine life.

\subsubsection{Urban development in coastal area}

Demand for development along the coastline becomes very significant because of strategic location for shipping and historic factors contribute towards land reclamation in coastal area especially in Penang and Johor state (west coast of Malaysia). There are about 22 urban settlements along the coastline of Malaysia consists of some major towns such as Georgetown, Malacca, Johor Bharu, Kuantan etc. and these towns are State Administrative or District Centres. There are rapid developments in coastal areas and the population in these coastal areas getting increase. Recently some large reclamation projects for urban expansion, ports and marina development have taken place in Penang Island, Straits of Malacca and Sepang Gold Coast. This Sepang Gold Coastline is environmentally 
sensitive area and includes mangrove swamps and mudflats which serve many functions such as buffer in protecting from disasters along coastal area such as tsunami, flooding, earthquake and also providing a nursing ground for fisheries.

These scenario causes pollution. Pollution is a more serious problem as it is endangering the existence of flora and fauna, contaminating the quality of river and water quality. Reclamations projects threaten the breeding and spawning grounds of fishes and places of tourist attraction. Besides that, mangroves have been demolished mainly for industrial and residential developments and also for aquaculture purpose. The development causes habitat degradation and polluted the seawater through sewage/domestic waste and industrial waste discharges, effluents from agricultural processing plants. Moreover, reclamation destroyed coastal habitats (potentially including mangroves and sea grass beds which is important for fish feeding and breeding areas) and cause coastal erosion indeed may even need to relocate the coastal communities as a direct result. A cost effective solution to one sector may be economically and environmentally detrimental to the needs of another sector. Therefore, it has now been recognised that effective management of coastal areas should be based not only on an analysis of individual activities and their impacts, but also on the combined effects of sectoral activities on each other and on coastal resources. A solid framework for marine environment management in Malaysia is still lacking despite the government's taken a lot efforts and commitment to manage and protect the country's coastal areas.

\subsubsection{Lack of coordination}

At present, government agencies are organized sectorally and serve primarily to administer their respective assigned responsibilities, especially as detailed in enabling legislation. The problem is compounded by the federal structure of Malaysia and resultant fragmentation between the Federal and State governments. There is no formal coordination procedure to enable respective government agencies to identify coastal zone problems that do not fall within immediate jurisdictional responsibility of a single agency. Implication of lack of communication between planners, managing government agencies and stakeholders restricted opportunities for local participation in decision making and development planning. The absence of a comprehensive, integrated national ocean policy has become an obstacle to the development of coordinated planning of maritime economic activities and in addressing issues relating to the protection of marine environment and resources.

\section{Approach and policies on coastal area planning and development}

Malaysia has taken into consideration activities as described in Agenda 21 and good practices as an approach for integrated management and sustainable development of coastal and marine areas. In Malaysia, three types of approaches are being practise in planning and development of coastal areas. The planning and management for projects that uses federal fund such as development of port, 
navy base, airport, highways etc. are base on Integrated Coastal Area and River Basin Management (ICARM) under Economic Planning Unit (EPU) whereas, state coastal area projects such as development of marinas, resort funded by private sectors are control and monitor by development control/planning approach. Meanwhile, management of coastal areas developments in west Malaysia is more towards state management approach by forming authority to plan and manage the coastal area and marine life.

\subsection{Integrated Coastal Area and River Basin Management (ICARM)}

These Integrated Coastal Area and River Basin Management (ICARM) provide the key to integrated development of natural, economic and cultural environments within river basins and coastal areas for federal government projects. Preparation of these ICARM involved varies government and private agencies. Implementation of these ICARM consist of multiple agencies to take into consideration about varies aspects such as social impacts, fishermen income, marine life etc. Besides that, a variety of tools and methods have been used for information gathering in ICARM for development plan and implementation programme. Geographic Information Systems (GIS), Decision Support Systems, Environmental Impact Assessment (EIA), Strategic Environmental Assessment (SEA), Carrying Capacity Analysis (CCA), have been used as instruments for project simulation and educational resolution. Through these tools the projects will be controlled and monitored more efficiently. Besides that, national level co-ordinating committee by Maritime Institute of Malaysia's (MIMA) to spearhead the planning and management of maritime economic activities in the country in collaboration with other agencies such as the Economic Planning Unit, National Maritime Council and National Development Planning Council is an action towards managing the coastal area in Malaysia. Beside that, National Policies such as Malaysia National Biodiversity Policy 1998 is set up to conserve biodiversity and optimise economic through biodiversity resources. National Policy on Wetland is a framework on promoting wetland conservation.

\subsubsection{National physical plan}

National physical plan is a study carried out at national level for better management of coastal development through identifying major coastal areas that measures need to be taken. These National Physical Plan is National Physical Plan was prepared to manage and planning peninsular of Malaysia till 2020. This plan has given emphasize in sustaining coastal planning and integrated with ICARM approach. Policies have been formulated that sensitive coastal ecosystems shall be protected and used in a sustainable manner. Among the measure that has been given priorities in coastal planning are as below:

- Coastal reclamation for future urban expansion shall not be carried out except for the development of ports, marinas and jetties.

Sensitive coastal ecosystems of national importance shall be gazetted as Protected Areas and could be utilised for low-impact nature tourism.

Other sensitive coastal ecosystem shall continue to be identified in the Structure Plan. 
- Adopt recommended by National Integrated Coastal Zone Management for coastal areas.

- Coastal area land use plan shall be prepared.

National Physical Planning Council in Malaysia has approved instruction that all development more than 20 hectares is compulsory to submit Environmental Impact Assessment (EIA) Report and all laws and rules are enforced immediately. These shows Malaysia has given more emphasize in management of coastal areas towards sustaining the marine life and social habitats in near future.

\subsubsection{Structure plan and local plan}

Beside National Physical Plan, management and development of coastal areas are given emphasize through preparation of development plans. Although the Town and Country Planning act do not specifically address coastal resources management into account, it does contain provisions that environmental concerns integrated into planning and development of coastal areas. This structure plan also underlines the policy and strategic on marina development in term of location suitable ability base on international market trend, consistent with development concept and environmental implications for the respective state. Detailing the policies on marina development such as type of marina, development component, location criteria, hydrology analysis, water movement system, supporting facilities, zone for public and local authority and also protection on Environmental Sensitive Area have been outline in managing coastal area. Through these approaches, environmental aspects have been given greater emphasis in the development plan how to manage, implementing and monitoring of maritime economic activities in the country though sensitive planning in the fields of coastal area is extremely crucial to protect Malaysia's maritime resources and preserve its maritime environment.

\subsection{Integrated Coastal Zone Management (ICZM)}

Beside these ICARM used by federal government, Sabah state has its own Integrated Coastal Zone Management (ICZM) to manage the coastal area for long term. Sabah particularly with regards to halting degradation of coral reefs, Integrated Coastal Zone Management (ICZM) has been implemented to threat the coastal resources with collaboration with local partners. The project was implemented in close collaboration with Town and Regional Planning Department in Sabah, Malaysia, Borneo Marine Research Institute of the University Malaysia Sabah and other agencies. The outcomes produced were really valuable results for coastal zone planning. The locations of the coral reefs are now digitised and incorporated in GIS of the Integrated Coastal Zone Management Unit of the Town and Regional Planning Department. The result of the analysis shows that excessive sedimentation from watershed does not directly affect the Kudat and Semporna coastline that have the greatest concentrations of coral reefs. However, in order to protect 'sensitive areas' consist the coastal areas that are within $400 \mathrm{~m}$ of coral reefs, these areas have been identified in coastal 
district in Sabah. The identification of this sensitive area has allowed to develop specific policies and regulations to classify land-uses for predominant use, restricted use, and prohibited use. This state management approach becomes significant on coastal zone planning and to do improvement of the statutory plan for Sabah.

\subsection{State development control}

Management of state coastal areas in Peninsular Malaysia have been practise through planning and development control approach. This approach is mainly used for private projects and also joint ventures projects that need to be submit the development proposal such as township, resort, jetty etc. irrespective of size to the respective state in order to get approval. These approaches also involve input and comments from multi government agencies before the project take place. Certain reports such as Environment Impact Assessment (EIA), simulation method for identifying the best location need to be produce by respective companies before approval are given. Planning and monitoring of coastal areas in states are handle on project basis because different consideration have to be given to different type of proposal depend on the nature of the proposal. Among other state government projects are such as land reclamation along coastal areas, reforest of mangrove land and contingency disaster plan etc.

\subsubsection{Reclamation of coastal area}

Land reclamation projects normally carried out by state with private sectors. In Malaysia, reclamation has taken place in Penang Island and Malacca to meet the urban needs. Limited of land in Penang Island forces the state government towards carrying out the reclamation of land. Indeed, this proposed land reclamation adds to silt problems and displacement and compensation to these local communities (fishermen livelihood). Imposing condition by state to comply with by the company undertaking the land reclamation project has been implemented such as s study on Penang Land Reclamation Possibility and public participation in development proposal have been carried out. Satellite images have been used to overview the land use changes along coastline from 1981 to 1996 and studies show about 620 hectares under land reclamation in Penang Island. A correct evaluation of costs and benefits of the proposed economic development as opposed to the benefits of the long term sustainability of the coastal resources and increase the quality of human settlement for the local community is necessary. Technical guidelines on the development and management of the coastal zone have been drawn up by the Department of Irrigation and Drainage Malaysia such as (i) establishing a setback limit for development of $60 \mathrm{~m}$ from the mean high water spring mark for sandy coastline and $400 \mathrm{~m}$ for a mangrove coast, (ii) providing protective structures against erosion for development requiring a coastal frontage (jetties), (iii) prohibiting sand extraction in shallow waters and ensuring proper disposal of sand and (iv) locating proposed development or relocating existing facilities further inland. 


\subsection{2 'Carrying capacity' studies}

Besides that, carrying capacity is another approach taken by Malaysian government is to maintain the sustainability of marine life especially. The concentration of coastal and island tourism development in peninsular Malaysia has generally followed a study conducted by the Tourism Development Corporation which identified six tourist regions which can be developed based on the presence of stretches of beaches and islands. The carrying capacity case study in Tioman Island and Langkawi Island were conducted to examine the status of the islands as developing tourist destination, especially with regard to coral reef tourism.

\subsubsection{Preserving and replanting of mangroves areas}

In Malaysian, it is estimated about $6,412 \mathrm{~km}^{2}$ is covered by mangrove area. It is important to preserve the multi-functional mangrove forests which often misconstrued as being smelly and of 'no use'. Research by experts showed that it will cost US $\$ 9,990$ (RM37,962) per hectare per year to use technology to replace the naturally available mangroves. As a long term measure, state governments in Malaysia through Forest Department gazetted mangrove areas as forest reserve from any prohibited development. Currently this department is managing the mangrove areas along the coastal. One of the best practises in mangrove management was done in Kuala Sepetang, Perak (west coast) coastal area. The main objective of these practises is to preserve the mangrove area by reforest of mangrove and this project was nominated the best mangrove management practise. Under these programme, Forest Mangrove Management Plan or Reforest of Mangrove Land have been prepared. The main objective of this programme is to gazette the state mangrove land. These gazette mangrove areas are significant to the ecosystem and humans such as:

- Protect coastline mangrove act as natural buffers, absorbing the force of waves and storms.

- Traps sediment to improve water quality.

- Provides food and nesting environment for wide variety of animals.

- Many commercially important species of fish, prawns and crabs can be caught near mangroves.

- Mangroves have always been an important source of logs and timber for construction, charcoal production and handicraft. Mangrove timber can last for a long time, even if submerged under water and is ideal for making fishing gear and boats.

Replanting of mangrove for reforest the mangrove area has been carried out as significant action along the coastal areas in certain state such as Penang, Malacca, Johor (west coast) in Malaysia. Converting the mangrove forest in Pulau Ketam in Selangor state (west coast) and the surrounding area into a forest reserve is one way preserving and rehabilitating. This project was implemented using the same method as Kuala Sepetang mangrove management project. It is also in line with Malaysia government call for preservation of mangrove swamps following the tsunami disaster in 26 December 2004 which cause 69 died and more RM200 million ringgit losses to the country. More 2000 families along 
coastal areas in west coast of Malaysia losses their home and properties. As consequences, there are tighter control once these mangrove areas becomes a forest reserve as loggers have to follow forest reserve rules and regulations, which includes buffer zones'. Enforcement of acts and fulfilling certain guidelines were also implemented to protect the coastlines. Environmental Quality Act and Regulations which stipulated that no activity related to project requiring Environment Impact Assessment may be carried out until the EIA report is submitted and approved. Besides that, fine not exceeding RM100,000 or imprisonment for period not exceeding five years or both are were taken are being enforce seriously.

\subsubsection{Alternative inland fishing concept}

Inland fishing concept has been introduced in Malaysia to generate income for the coastal communities that mainly depends on fishing activities. This concept was introduced mainly in east coast of peninsular of Malaysia because these fishermen couldn't go to the sea during monsoon season. The situation will affect the fishermen income in coastal areas. These inland fishing projects were carried out in swampy areas, ex-mining pools, river banks and eroded land/muddy land. The objectives of the inland fishing projects are to generate supplementary income to the fishermen communities along coastal areas. This overly simplistic approach was followed in both the USA (MacCall, 1989; Larkin, 1991) and Norway (Griffin, 1993) for over half a century with no demonstrable effects on the targeted fishery. More recently, many marine stock enhancement programmes in developing countries like Malaysia have been established to enhance fisheries that have declined as a result of habitat degradation and over fishing (Danielssen and Moksness, 1994). Inland fishing project also increases the supply of high grade fish, prawn, crabs as an alternative beside deep sea catchments. Nearly all of the marine enhancement programmes, with the exception of commercial aquaculture, are government supported, thus they also serve as a visible indication that the government is trying to manage and/or promote marine resources. The other intentions of the inland projects are also providing protein food to the Malaysian communities. This inland fishing becomes functional to the local the fishermen communities. Given current technology, it will nearly always be possible to increase production from marine, coastal and inland areas.

\section{Conclusion}

Environmental problems due to the human impact of growing urban populations in coastal areas necessitate an integrated approach to coastal resource management as a move toward sustainable development. The approaches taken in Malaysia proven good practices towards balancing the human and environment needs in coastal areas planning. Local communities who really depend on coastal life livelihood are taken into consideration before any developments are approved by either federal or state government. Preservation and replanting of mangrove areas are given attention towards sustaining the 
coastal areas ecology. Therefore, a need to bring sectoral activities together to achieve a commonly acceptable coastal management with giving more emphasise on environmental along coastline is necessary towards sustainable developments.

\section{References}

[1] Economic Planning Unit, Prime Minister Department, Malaysian Integrated Coastal Zone Management Policy, 2004.

[2] Economic Planning Unit, Prime Minister Department, Malaysian Integrated Coastal Zone Management Policy - Issues, Strategies and Action Plan. 2004.

[3] Lim Ching \& Nathaniel Spring, The Concept and Analysis of Carrying Capacity, Case Study: Pulau Tioman, 1995.

[4] Town and Country Planning Department, Ministry of Housing and Local Government, Current Planning Approval Process For Coastal Zone Development in Malaysia. 1993.

[5] Department of Irrigation and Drainage, Malaysia, Coastal Zone Management in Malaysia. 1994.

[6] Timorthy Beatley, David J. Brower, Anna K. Schwab, Coastal Zone Management. 1998.

[7] New Straits Times Press, Page 11, 29 March 2005.

[8] Sabah Town and Country Planning Department, Integrated Coastal Zone Management (ICZM), 1996. 